\title{
Thought on Design of Chinese University Campus under the Background of Internet Era
}

\author{
Li Jing ${ }^{12}$ Ma Xin ${ }^{1}$ \\ ${ }^{1}$ Architecture School ,North China University of Technology ,Beijing, 100144 \\ ${ }^{2}$ Architecture School, Tianjin University, Tianjin , 300072
}

\begin{abstract}
Internet is the main characteristics of this era. Under the influence of internet, students' codes of conducts and ways of thinking have undergone tremendous changes. Internet life made campus life and social life blurred and tempo-spatial correlation between teaching and learning vaguely outlined, and fundamental changes have thus taken place in spatial characteristics of the university campus as the result. Such changes require future campus planning and construction to embody the characteristics of the times and meet the interest demand of served groups. This article aims to summarize the spatial characteristics of the university campus in the Internet era through analysis and discussion on campus spatial characteristics, in order to guide future campus planning and design.
\end{abstract}

Keywords : Internet era; University Campus; Spatial Characteristics

Since the first e-mail was sent in China in 1987, up to now the number of netizens in China has reached 591 million, and the number of people who access the internet through mobile phones hit 420 million. China has become "the most populous country" on the Internet. However, college students are exactly the most active group among Chinese netizens. The 32nd Statistical Report on China Internet Development released by China Internet Network Information Center (CNNIC) in Beijing showed that by the end of June 2013, Chinese netizens had reached 591 million, which was 26.56 million more than that number at the end of 2012, and the Internet penetration was $44.1 \%$. According to China Statistical Yearbook 2012, by the end of 2012, the number of college students had reached 25.365647 million, and almost all of them were netizens. The rise of the Internet has created a brand new social living space featured with informatization, digitalization, networking and internet fiber, and its huge power is changing people's behaviors and ways of thinking.

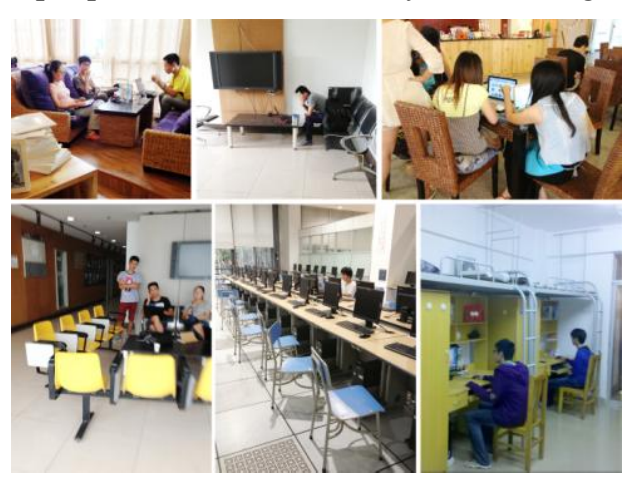

Fig. 1 Network Usage on University Campus Data Resource: Photos Taken by the Author 
People can enjoy the rich information flow, broad field of vision, and brand new life style that the Internet brings. With the new life style, campus group, as the representative of new generation and the newest innovation strength in the society, has also undergone fundamental changes: study style, life style and education mode have gradually endured dramatic changes. As regards media, teleeducation, internet management, paperless system, digital security, campus e-card, digital library, etc., new requirements have been proposed for campus planning and construction. Combined with the characteristics of the Internet era, the architectural design and planning of university campus will become much more digitalized, humanized and intelligentized.

However, "technology is a doubleedged sword". Nowadays, the education mode and life style are undergoing tremendous changes, the traditional campus planning and design mode has been challenged and questioned: interpersonal indifference, reduction of face-to-face talk, and collision of ideas. So, what are the spatial characteristics of campus under the background of Internet era? How to make the space meet the change in people's codes of conducts and ways of thinking?

\section{Review on Research Status Quo and Planning Issues}

University campus planning and design has always been a hot spot issue in the realm of architectural planning and construction in China, since colleges and universities serve as a special urban functional structure that is densely populated and has special positions and complete functions in a city. Numerous colleges and universities in China also enjoy rapid construction and development while the city is undergoing rapid development. Under the support of national policies and the enrollment peak of China, university campus planning and construction play an important role in urban construction. As a result, university campus planning and construction also becomes a hot topic.

He Jingtang ${ }^{1}$, the academician of the Chinese Academy of Engineering (CAE), proposed the development trend and characteristics of campus planning in the new era in multiple articles, i.e. diversification and integration of education mode, humanization and ecologicalization of space environment, socialization and opening of spatial layout, and grouping and networking of campus buildings. In the University Campus Planning and Architectural Design (2006), Song Zefang and Zhou Yihu, by starting from the overall planning and environment design, gave an introduction to campus location selection, overall planning, campus architectural space planning and art layout, environmental planning and design, campus reconstruction and expansion, and etc. In the New Period Features of College and University Campus Planning and Construction in China, Peng Mei summarized the features of campus construction features in the new period and discussed such issues as the type, change, humanization and ecologicalization of campus planning and construction in the new period, mentioned the digital campus in the information era, and briefly narrated the obvious digitalization and intelligentization features of campus planning in the Internet era; however, any in-depth discussion has not yet been conducted.

According to associated references, the current researches on campus planning at home focus on overall campus planning and design, campus public space system, single building on campus, campus planning history, ecological-friendly campus and other subjects, while the researches on internet and campus focus on

\footnotetext{
${ }^{1}$ He Jingtang, Several Trends in Campus Planning and Design [J]. New Architecture, 2002(4), 5-7.
} 
campus internet construction, psychological impact of internet on students, change in students' life arising from internet, construction of digital library, and other subjects. Such researches emphasize either the design of campus space or the impact of internet on individual student's behaviors. However, only a few researches are conducted on the campus space demands caused by the impact of internet on behaviors.

In the meanwhile, the campus planning and architectural design of colleges and universities in China follow Code for University Campus Planning and Design ([No. 245], 1992). Therefore, there are insufficient design codes and researches on how to perform university campus planning and design in a better way in the Internet era.

\section{Behavioral Characteristics of Campus Life under the Background of Internet Era}

\subsection{Lifestyle change - blurred bounda- ry between campus life and social life}

Students shop on "Taobao.com", purchase electronic products on "360buy Jingdong Mall", buy books on "dangdang.com", and order take-away food via "home delivery services", boys call themselves "Picasso (indoors boys)", and girls call themselves "Marie $\mathrm{Cu}$ rie(indoor girls)", which are the indications of college students' life on campus under the background of Internet era. Internet causes great changes in students' life, and students successfully get rid of the previously limited campus life when the internet was not so popular and get more involved in social life.

In the era when internet was not so popular before, the living space of college students mainly included the following functional spaces: dormitory, classroom, library, canteen and recreation center. The students' life was restricted by space to a large extent. They had a higher demand for various functional spaces, and there was a considerable boundary between campus life and social life. Nowadays, internet is getting more and more popular; the students' campus life is covered by online shopping, online chat, online video, and online learning, etc.; campus life and social life are made blurred day by day; various services from the society are delivered to every corner on campus, and the life style of students is getting increasingly similar to that of social groups, so that the university campus need to be more open and the facilities serving for student's life are required

\begin{tabular}{|c|c|c|c|c|c|c|c|c|c|c|}
\hline & University & $\begin{array}{l}\text { Activity } \\
\text { Center }\end{array}$ & $\begin{array}{l}\text { Fitness } \\
\text { Center }\end{array}$ & $\begin{array}{l}\text { Hair } \\
\text { Salon }\end{array}$ & Cafe & $\begin{array}{c}\text { Dry } \\
\text { Cleaner }\end{array}$ & Theater & Museum & $\begin{array}{l}\text { Book } \\
\text { Club }\end{array}$ & $\begin{array}{l}\text { Express } \\
\text { Delivery }\end{array}$ \\
\hline & Peking University & & & & & & & & & \\
\hline & Renmin University of China & & & & & & & & & \\
\hline Original & Tongji University & & & & & & & & & \\
\hline Campus & Wuhan University & & & & & & & & & \\
\hline & $\begin{array}{l}\text { Huazhong University of } \\
\text { Science \& Technology }\end{array}$ & & & & & & & & & \\
\hline & $\begin{array}{c}\text { Shenyang Jianzhu Universi- } \\
\text { ty }\end{array}$ & & & & & & & & & \\
\hline & $\begin{array}{l}\text { Zijingang Campus, } \\
\text { Zhejiang University }\end{array}$ & & & & & & & & & \\
\hline & $\begin{array}{c}\text { Xiangshan Campus, China } \\
\text { Academy of Art } \\
\end{array}$ & & & & & & & & & \\
\hline & Jiangnan University & & & & & & & & & \\
\hline
\end{tabular}

Table 1 Status Quo of Living 5 acilities Provided in Campuses

Data Source: Drawn by the Author (if the facilities are made available, the associated blank is marked with color) 
to emulate the supporting facilities of residential area. Students' demand for individual campus life is prone to residents' demand for supporting facilities in residential area. For instance, students need activity centers, fitness centers, hair salons, restaurants and dry cleaners and other supporting facilities that can meet immediate needs to provide instant services.

\subsection{Change of learning style - vaguely outlined tempo-spatial correlation be- tween space teaching and learning}

Internet dissemination has very distinctive features: extensive dissemination, optional information, multimedia information, real-time and interactive information exchange. Under the influence of these features, the teaching and learning style are changed greatly: diversified teaching organization forms; interactive teaching method; friendly relationship between teachers and students; expanded space-time during teaching process; blurred boundary between education and work. Under the influence of internet, time and space boundary are increasingly blurred in terms of the learning style; "studying in classroom and reading books in library only" are not the typical campus life any longer. The students may learn in every corner on campus, and their learning style is becoming more and more active and purposeful. Moreover, the students are involved in a wider range of fields, the teaching method requires students to be more interactive, and the students rely on resource sharing to a larger extent.

Due to the change of learning style, the time and space boundaries of teaching and learning on university campus get vaguely outlined over time, and the students can gain easy access to knowledge provided by the teacher on the Internet. At present, various teaching resources from famous schools and renowned teachers are made available on the Internet. Under this background, great importance is particularly attached to the sharing of facilities on university campus and the arrangement of information exchange and communication spaces. The single-sided "cramming" method of teaching certainly fails to meet the students' demand in Internet era. In a sense, what the students need is face-to-face communication, issue-specific discussion and enlightenment with the aid of the teacher.

\section{Basic Characteristics and Space Layout Planning Method of Universi- ty Campus in Internet Era}

\subsection{Diversified supporting facilities: The layout of public facilities should be diversified to meet the service radius}

Due to the blurred boundary between campus life and social life, the dormitory, as the conventional living space of the students, as well as associated simple public facilities, cannot meet the demands of college students any longer. College students' demand in

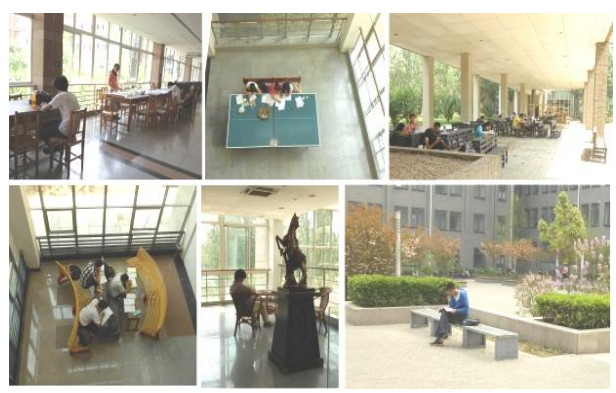

Fig. 3:Learning Space Survey Data Source: Drawn by the Author

terms of life quality and content becomes more and more diversified: their demand for various social living facilities is increasing, including fitness, recreation, study, cosmetology, communication, etc. In the interview towards several universities in Beijing, it is found that supporting 
facilities meeting the times are unavailable in a considerable number of schools, such as professional fitness facilities, professional hairdressing facilities, cafe, and small book club. College students are part of social groups who are completely involved in the society rather than a separate group in the society, which means the future functional arrangement and public facilities arrangement on university campus should be more diversified and service radius should be taken into account as for large scale new campuses. The progress in social life boosts the students' additional demand except for basic life.

\subsection{Multifunctional space: The com-}

\section{munication space should be included in} major functional spaces of university

As regards teaching in universities in Internet era, the time and space of teaching and learning are getting blurred. Classroom education is no longer the most critical part in university education. Instead, communication and sharing gradually become the major teaching method in universities. Students access to various teaching and learning materials via computers and internet. As a result, in use of space function, communication space should be increased. Furthermore, the space for communication of students, self-study and discussion with teachers should be expanded in teaching buildings, dormitory, and activity center, and the like. Concerning the use and design of space function, multiple functions shall be integrated as a whole. Taking U-town built recently in the National University of Singapore for example, a lot of small seminars are added in the design of students' activity center, and small-sized equipment for students such as projecting apparatus are arranged in the small seminars, which considerably facilitate selfstudy and discussion of students and achieve fantastic teaching effect. In addi- tion, the space is designed to be multifunctional. Clear division of teaching and living areas is against the college students' life and use requirements.

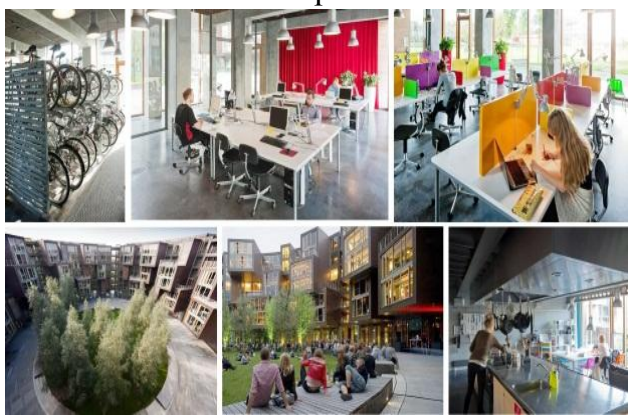

Fig.4 Dormitory of University of Copenhagen Data Source: Photos from Baidu

\subsection{Prolonged use time: The layout of} functional zones is not applicable to university campus in Internet era any longer

Campus life in Internet era appears rich and colorful. Since resource sharing becomes more and more popular, the occupation time for various facilities on university campus is prolonged in Internet era. Students require making various facilities available for them at anytime in $24 \mathrm{~h}$ every day. Thus, the traditional "onesize-fit-all" functional layout becomes inappropriate for university campus in Internet era. The prolonged use time requires the campus space layout to break the traditional functional zoning. The campus space should be small but multifunctional. Teaching buildings need to be combined with certain small-sized leisure facilities, e.g. cafe, book club, communication and discussion space. Moreover, spaces for special purpose shall be added according to the use requirements of different disciplines. 


\subsection{Increasing use demand: A wide range of spaces are available to meet the demand of different groups of peo- ple}

As for dormitory, with the development of the times and renewal of people's concepts, currently universities recruit students from the whole society. In this way, all kinds of people are admitted to universities, including the conventional full-time students, senile or married students with a high educational background, and international students, etc. Consequently, the conventional simplex dormitory form cannot meet the latest requirements of the students. The type of students' living space should also be diversified. The buildings may include high-rise buildings, multi-story buildings, and lowrise buildings; the plan layout of buildings should include dormitories, apartments, and separate small houses, etc.; apart from living space, the functional space should involve daily life, bathroom, kitchen, study room, communication corner, storage room, balcony, loft and other spaces; the type of space may not be limited to the traditional straight line and square, curve and irregular space, etc. can also be taken into consideration. Different types of spaces may be combined to meet the requirements of different numbers of occupants and different living requirements.

\section{Conclusion}

Numerous students in the ivory tower are the mainstay for the development of all industries in the future. University campus serves as the cradle for nurturing the students. In the critical stage for comprehensive transformation and upgrading of the current education mode, the future university campus planning needs to adapt to the demand change and social economy operation mode formed in this period and to further adapt to the interest demand related to the education mode under diversified educational background in the future.

Research for this paper was supported by funding from:

. MOE (Ministry of Education in China) Project of Humanities and Social Sciences---Youth Fund (Project

No13YJCZH080.) AND Academic Human Resources Development in Institutions of Higher Learning Under the Jurisdiction of Beijing Municipality, PHR(IHLB),

(PHR201108066) AND.Beijing municipal philosophy and social science planning project. (12CSC013)

\section{References}

[1] Tu Huijun, et. al., Overall Design of University Campus [M]. Beijing: China Architecture \&Building Press, 2007.3-49

[2] Song Zefang and Zhou Yihu, University Campus Planning and Architectural Design [M]. Beijing: China Architecture \&Building Press, 2006

[3] He Jingtang, Several Trends in Campus Planning and Design [J]. New Architecture, 2002(4), 5-7.

[4] He Jingtang, Ecological Internet of Science \& Technology Park- Conceptual Planning and Design for National University Science Park at Jiangning Campus of Southeast University [J]. Urban Planning, 2002(10), 53-54.

[5] He Jingtang, Concept_ Practice _ Outlook _ Contemporary University Campus Planning and Design [J]. Chinese Science Paper Online, 2010(7), 489-493.

[6] Xue Xinxin, Study on Planning and Design of Contemporary Chinese Largescale University Campus from a New Perspective [D]. Hangzhou: Zhejiang University, 2011.

[7] Yu Yiwen, Research and Practice on Cost-effective University Campus Planning and Construction [D]. Changsha: Central South University, 2009.

[8] Zhang Fangping, Study on Teaching in Internet Era [J]. Journal of Ningbo Polytechnic, 2008(12), 51-53.

[9] Wei Xu, Rise of Internet and Evolution of Modern Education [J]. Journal of Jiangsu Institute of Education, 2001(17), 23-25. 
[10] Yan Jianwei and Wang Xiaohan, Growing University Campus Planning [J]. Architectural Journal, 2005(3), 11-13.

[11] Chen Jiaqi, Study on Public Space in University Campus from the Perspective of Student's Demand [J]. Shanxi Architecture, 2007(7), 34-35. 